\title{
KELAYAKAN USAHA PEMBIBITAN MANGGA VARIETAS AGRIMANIA PADA AGRIMANIA FLORA
}

\author{
Abiyasa Tunjung Purbawasesa ${ }^{1}$,Teguh Imam Santoso ${ }^{2}$, Fadhilah Laila $^{3}$ \\ 1,2,3 Program Studi Agribisnis, Fakultas Pertanian, Universitas Wiralodra \\ Email : abaytp97@gmail.com ${ }^{1}$, teguhimans@unwir.ac.id², fadhillahlaila@gmail.com
}

\begin{abstract}
ABSTRAK
Usaha pembibitan Mangga Agrimania memiliki potensi komoditas ekspor untuk mengatasi kendala dalam memproduksi buah mangga. Tujuan penelitian ini untuk mengetahui tingkat kelayakan usaha pembibitan mangga baik sebelum adanya penambahan lahan maupun setelah adanya penambahan lahan. Penelitian dilaksanakan di Usaha Pembibitan Mangga Agrimania pada Agrimania Flora Indramayu Desa Jatisura Kecamatan Cikedung Kabupaten Indramayu. Waktu penelitian dilakukan selama bulan Oktober 2018 sampai Agustus 2019. Penelitian ini menggunakan Analisis Kelayakan Usaha baik non-finansial maupun finansial serta analisis sensivitas. Berdasarkan hasil analisis dari aspek non-finansial, usaha pembibitan Mangga Agrimania pada Agrimania Flora Indramayu dapat dikatakan layak. Hasil analisis pada aspek finansial usaha pembibitan Mangga Agrimania ini layak untuk dijalankan, karena besarnya nilai R/C sebesar 5,41, NPV sebesar Rp.3.184.056.362,63, IRR sebesar 67\%, Net B/C sebesar 6,54 dan Payback Period selama 4 tahun 2 bulan 10 hari. Hasil analisis nilai pengganti menunjukkan bahwa usaha pembibitan Mangga Agrimania pada Agrimania Flora Indramayu tidak sensitif terhadap kenaikan harga input biaya variabel. Jika terjadi kenaikan harga pada biaya input produksi, seperti kenaikan harga biji batang bawah tanaman mangga meningkat lebih dari $7.140 \%$ atau kenaikan harga pupuk dan pestisida meningkat lebih dari $11.080 \%$, maka usaha pembibitan Mangga Agrimania pada Agrimania Flora Indramayu menjadi tidak layak untuk dilaksanakan. Karena jika terjadi peningkatan harga lebih dari itu, maka NPV kurang dari 0 , IRR kurang dari 17,5\%, Net B/C kurang dari 1.
\end{abstract}

Kata kunci : Kelayakan usaha, Mangga Agrimania, Pembibitan

\section{PENDAHULUAN}

Tanaman mangga ialah tanaman buah tahunan berupa pohon yang berasal dari negara India. Tanaman ini kemudian menyebar ke wilayah Asia Tenggara termasuk Malaysia dan Indonesia. Mangga berasal dari family Anarcadiaceae, genus Mangifera, species Mangifera indica (Singh, 1969 dalam Oktavianto et al., 2015).

Tanaman mangga telah menyebar ke seluruh wilayah Indonesia terutama di wilayah Kabupaten Indramayu, Provinsi Jawa Barat yang merupakan sentra produksi buah mangga terbesar di Indonesia. Indramayu sebagai sentra produksi buah mangga memiliki luas panen, produksi dan produktivitas yang cukup tinggi (Tabel 1.).

Tabel 1. Luas panen, produksi dan produktivitas mangga di Kabupaten Indramayu tahun 2013-2017 


\begin{tabular}{cccc}
\hline Tahun & Luas Panen (Pohon) & $\begin{array}{c}\text { Jumlah Produksi } \\
\text { Mangga (Kw) }\end{array}$ & $\begin{array}{c}\text { Jumlah Produktivitas } \\
\text { (Kw/Pohon) }\end{array}$ \\
\hline 2013 & 660.147 & $847.878,00$ & 1,28 \\
2014 & 1.153 .176 & $1.156 .366,00$ & 1,00 \\
2015 & 491.494 & $712.817,96$ & 1,45 \\
2016 & 575.234 & $143.614,82$ & 0,25 \\
2017 & 436.969 & $774.729,77$ & 1,77 \\
\hline
\end{tabular}

Sumber : Badan Pusat Statistik Kabupaten Indramayu (2018)

Mangga Agrimania merupakan mangga varietas baru yang masih dikembangkan dan belum banyak dibudidayakan. Hal tersebut terjadi karena tidak diimbangi dengan banyaknya produksi, harga jualnya pun melambung tinggi hingga mencapai harga Rp.100.000/kg pada tahun 2014. Produksi buah mangga yang sedikit dan harga jual yang tinggi menjadi suatu kendala dalam memenuhi kebutuhan permintaan dan kepuasan konsumen. Adanya kendala dalam memproduksi buah mangga disiasati dengan usaha pembibitan Agrimania Flora Indramayu.

Kegiatan penjualan bibit Mangga Agrimania sudah berlangsung cukup lama, yaitu sudah berjalan dari tahun 2014 sampai sekarang. Kapasitas produksi bibit mencapai 20.000 bibit/tahun pada tahun 2018. Untuk mencapai kapasitas produksi tersebut, maka dilakukan pembibitan di lahan seluas 0,05 ha di pekarangan rumah di Desa Nunuk Kecamatan Lelea Indramayu dan penambahan lahan di tempat lain seluas 1,54 ha di Desa Jatisura Kecamatan Cikedung Indramayu.

\section{METODE PENELITIAN}

\section{Lokasi dan Waktu Penelitian}

Lokasi penelitian ini dipilih secara sengaja (purposive) yang dilakukan di Desa Jatisura Kecamatan Cikedung Kabupaten Indramayu pada Usaha Pembibitan Mangga Agrimania pada Agrimania Flora Indramayu. Kegiatan pengambilan data dilakukan sejak Oktober 2018 hingga Februari 2019.

\section{Metode Pengumpulan Data}

Metode penelitian yang digunakan dalam penelitian ini adalah metode pengembangan yang didalamnya berupa deskriptif. Desain penelitian yang digunakan dalam penelitian ini adalah survei deskriptif.

Jenis dan sumber data yang digunakan dalam penelitian ini adalah data primer dan data sekunder, baik yang bersifat kualitatif maupun kuantitatif. Teknik pengumpulan data yang digunakan pada penelitian ini adalah sebagai berikut :

1. Observasi atau pengamatan adalah suatu metode yang dilakukan untuk mendapatkan/memperoleh fakta-fakta yang diperlukan berdasarkan pengamatan peneliti.

2. Wawancara atau interview adalah kegiatan mencari bahan berupa keterangan maupun pendapat melalui tanya-jawab secara lisan dengan siapa saja yang diperlukan.

3. Studi literatur adalah kegiatan menelusuri sumber-sumber bacaan dari buku teks, jurnal, periodical, yearbook, bulletin, circular, leaflet, annual review, dan beberapa sumber bacaan lain.

\section{Metode Analisis Data}

Metode analisis data yang digunakan dalam penelitian ini yaitu analisis kualitatif dan analisis kuantitatif. Analisis kualitatif digunakan untuk menggambarkan aspek non-finansial di dalam penelitian dengan alat bantu kuesioner seperti aspek teknis, aspek pasar, aspek sosial-ekonomi-budaya, aspek manajemen dan hukum, aspek lingkungan. Sedangkan analisis kuantitatif digunakan untuk menilai kelayakan usaha dalam penelitian dengan alat bantu Microsoft Excel dan menggunakan rumus 


\section{Revenue Cost Ratio (R/C)}

Revenue Cost Ratio (R/C), yaitu hasil pembagian antara penerimaan dengan biaya total. Untuk menentukan kelayakan usahatani digunakan rumus :

$$
\mathrm{R} / \mathrm{C}=\frac{T R}{T C}
$$

\section{Net Present Value (NPV)}

Net Present Value (NPV) adalah manfaat bersih sekarang yang diperoleh selama umur usaha. Dengan demikian NPV merupakan selisih antara nilai sekarang (present value) dari manfaat (benefit) dan dari biaya (cost) pada tingkat suku bunga tertentu. Secara matematis, NPV dirumuskan sebagai berikut : Tiga kriteria kelayakan finansial berdasarkan NPV, yaitu :

$$
N P V=\sum_{i=1}^{n} \frac{B-C}{(1+i)^{t}}
$$
a. $\quad$ NPV $>0 \quad$ : Maka layak diusahakan
b. $\quad \mathrm{NPV}=0 \quad$ : Tidak untung maupun rugi
c. $\quad$ NPV $<0 \quad$ : Tidak layak diusahakan

\section{Internal Rate of Return (IRR)}

Tingkat pengembalian internal atau Internal Rate of Return (IRR) merupakan parameter yang dipakai apakah suatu usaha mempunyai kelayakan usaha atau tidak. Secara matematis dirumuskan sebagai berikut :

$$
I R R=i_{1}+\frac{N P V_{1}}{N P V_{1}-N P V_{2}}\left(i_{2}-i_{1}\right)
$$

Kriteria kelayakannya, yaitu :

a. IRR > i : Maka usaha layak dan dapat dilanjutkan.

b. $I R R=i$ : Maka usaha tidak menguntungkan dan tidak merugikan

c. IRR < i : Maka usaha tidak layak dan lebih baik mempertimbangkan kembali apakah melanjutkan usaha tersebut atau tidak.

\section{Net Benefit-Cost Ratio (Net B/C)}

Net B/C merupakan perbandingan antara NPV dari total benefit bersih terhadap total biaya bersih. Net $\mathrm{B} / \mathrm{C}$ digunakan untuk ukuran tentang efisiensi dalam penggunaan modal. Secara matematis Net B/C dapat dirumuskan sebagai berikut :

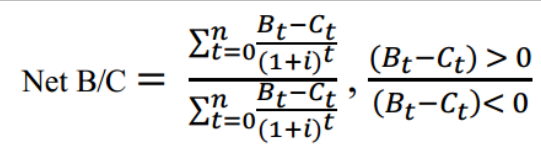

Kriteria kelayakan pada metode $\mathrm{Net} \mathrm{B} / \mathrm{C}$ adalah sebagai berikut :
a. $\quad \mathrm{Net} \mathrm{B} / \mathrm{C}>1$
: Maka usaha akan memperoleh keuntungan
b. $\quad \mathrm{Net} \mathrm{B} / \mathrm{C}<1$
: Maka lebih baik tidak diusahakan

\section{Payback Period (PP)}


Payback Period adalah suatu periode yang diperlukan untuk menutup kembali pengeluaran investasi dengan menggunakan aliran kas. Kriteria ini mengukur seberapa cepat pengembalian investasi pada suatu usaha. Secara matematis dapat dirumuskan sebagai berikut :

$$
\text { Payback Period }(\mathrm{PP})=\frac{\text { Investasi }}{\text { Keuntungan }} \times 1
$$

Kriteria penilaiannya adalah jika payback period lebih pendek waktunya dari maksimum payback period-nya maka usulan investasi dapat diterima. Namun jika payback period lebih lama dari maksimum payback period-nya, maka usaha/bisnis ditolak.

\section{HASIL DAN PEMBAHASAN}

\section{Struktur organisasi usaha}

Usaha pembibitan Mangga Agrimania merupakan usaha milik pribadi H. Urip yaitu Agrimania Flora Indramayu. Tergolong dalam Kelompok Tani Hortikultura Agrimania sehingga struktur organisasi yang dimiliki usaha ini masih tergolong ke dalam struktur kelompok tani karena belum memiliki badan usaha dan usaha pembibitan ini dikelola secara pribadi oleh $\mathrm{H}$. Urip (terpusat). Berikut adalah struktur organisasi Kelompok Tani Hortikultura Agrimania pada Gambar 1.

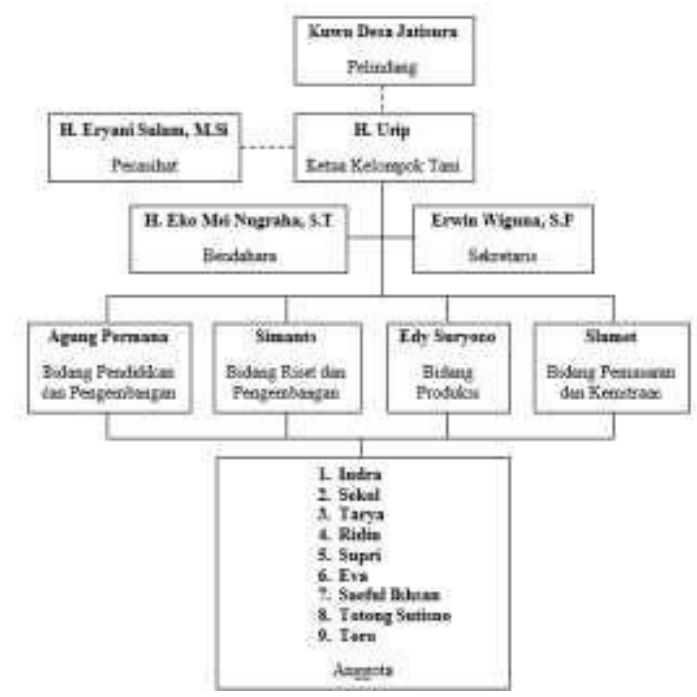

Gambar 1. Struktur organisasi Kelompok Tani Hortikultura Agrimania

\section{Analisis Aspek Non-Finansial}

\section{Aspek teknis}

Analisis terhadap aspek teknis yang dilakukan dalam penelitian ini meliputi pemilihan lokasi usaha dengan variabel utama dan variabel bukan utama, luas produksi, proses produksi, dan tata letak (layout).

a. Pemilihan lokasi usaha dengan variabel utama

Ketersediaan bahan baku, letak pasar yang dituju, tenaga listrik dan air, supply tenaga kerja, fasilitas transportasi.Usaha pembibitan Mangga Agrimania ini terdapat beberapa bahan baku yang digunakan dalam perbanyakan tanamannya antara lain batang atas (entres), batang bawah (semua varietas, diantaranya cengkir dan arumanis), polybag, plastik, tanah humus, sekam atau kompos, dan pupuk serta pestisida.

Usaha pembibitan Mangga Agrimania ini menghasilkan output berupa bibit berukuran 0,5-0,6 $\mathrm{m}, 1 \mathrm{~m}$ dan 2,5 m. Berbagai macam ukuran tersebut disediakan untuk menyesuaikan kebutuhan konsumen akan permintaan terhadap bibit dengan kisaran harga yang telah ditentukan dengan pemasaran bibit Mangga Agrimania ini dikirim ke seluruh Indonesia. Berikut adalah penyebaran benih 
Mangga Agrimania pada tahun 2015-2017 (Tabel 2).

Tabel 2. Penyebaran bibit Mangga Agrimania dari tahun 2015-2017

\begin{tabular}{ccc}
\hline No. & Lokasi Penyebaran & Jumlah (Bibit) \\
\hline 1. & Bibit & 2.500 \\
2. & Manokwari & 800 \\
3. & Raja Ampat & 300 \\
4. & 900 \\
5. & Bontang, Kalimantan Timur & 450 \\
6. & Kabupaten Kerinci, & 3.000 \\
7. & Jambi & 250 \\
8. & Jonggol, Bogor & 200 \\
9. & Purwakarta, Jawa Barat & 400 \\
10. & Subang, Jawa Barat & 2.000 \\
\hline Jumlah Total & Sulawesi & 10.800 \\
\hline
\end{tabular}

Sumber : Dinas Pertanian Kabupaten Indramayu (2018)

Ketersediaan air dalam kegiatan pembibitan Mangga Agrimania ini membutuhkan banyak air untuk berbagai keperluan. Sumber air yang digunakan saat ini berasal dari pompa benam (submersible pump). Kegiatan pembibitan Mangga Agrimania merupakan jenis usaha yang membutuhkan ketersediaan tenaga listrik secara berkala untuk penyiraman tanaman. Karena setiap aktivitas perkebunan seperti penyiraman tanaman yang melalui sprayer yang tersambung selang air dari pompa benam perlu dialiri listrik.

Ketersediaan tenaga kerja pada usaha pembibitan Mangga Agrimania ini berasal dari masyarakat di sekitar daerah tempat kebun usaha yaitu Desa Jatisura, Kecamatan Cikedung dan masyarakat di sekitar sekretariat kelompok tani yaitu di Desa Nunuk, Kecamatan Lelea. Tenaga kerja harian yang bekerja dalam usaha pembibitan ini mencapai jumlah 12-13 orang, namun terhitung ratarata pekerja tetap harian yaitu 5 orang.

Fasilitas transportasi untuk pengiriman bibit yang digunakan adalah mobil pribadi pemilik usaha yang juga digunakan untuk pembelian bahan baku utama, kecuali biji batang bawah dan tanah yang dikirim oleh truk pengangkut milik pemasok, dan juga pengiriman bibit bisa dilakukan melalui ekspedisi pengiriman.

b. Tata letak (layout)

Layout pada sebuah usaha adalah proses penataan seluruh sumber daya yang dimiliki oleh perusahaan guna mencapai keseimbangan kegiatan operasi secara efisien. Pada Gambar 2. memperlihatkan layout tempat kebun usaha Pembibitan Mangga Agrimania pada Agrimania Flora Indramayu di Desa Jatisura Kecamatan Cikedung Kabupaten Indramayu.

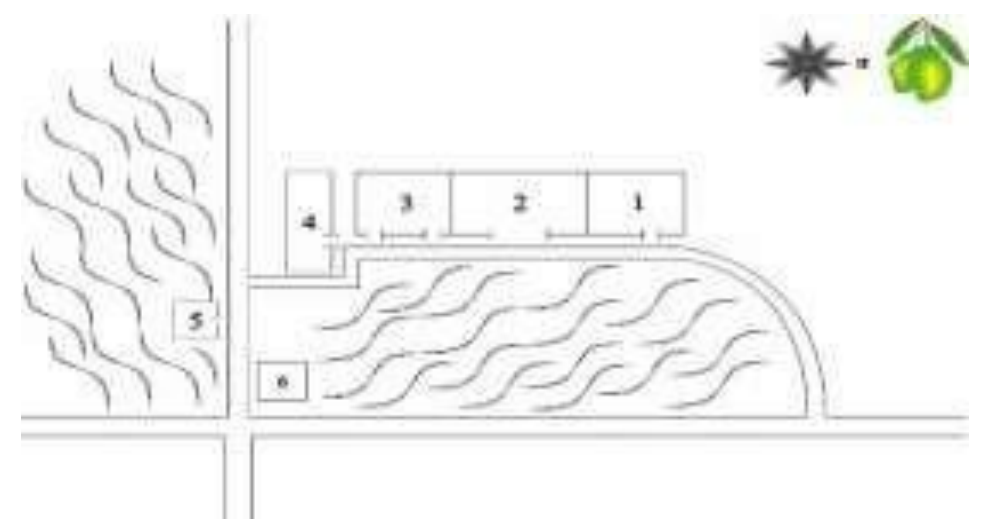

Gambar 2. Layout kebun usaha pembibitan Mangga Agrimania pada Agrimania Flora Indramayu 


\section{Aspek pasar}

a. Analisis peluang pasar

Jumlah permintaan bibit Mangga Agrimania yang diterima oleh Agrimania Flora Indramayu sebanyak $95 \%$ permintaan daripada jumlah produksi yang ditawarkan. Setiap tahunnya rata-rata permintaan bibit Mangga Agrimania kepada Agrimania Flora Indramayu sebesar 19.000 bibit sedangkan penawaran perusahaan mencapai 20.000 bibit. Selisih permintaan dan penawaran tersebut terdapat peluang 5\% yang mampu dimanfaatkan oleh Agrimania Flora Indramayu.

b. Analisis pesaing

Pesaing adalah perusahaan lain yang merupakan penangkar benih yang memproduksi produk pembenihan tanaman buah yang sama. Pesaing dari usaha pembenihan tanaman buah terutama pembibitan Mangga Agrimania pada Agrimania Flora Indramayu merupakan perusahaan penangkar benih pembibitan mangga lainnya yang menghasilkan varietas berbeda.

c. Bauran pemasaran

1) Produk (Product)

Produk yang dihasilkan oleh usaha pembibitan Agrimania Flora Indramayu ada tiga, antara lain bibit Mangga Agrimania dengan ukuran 0,5-0,6 m, $1 \mathrm{~m}$, dan 2,5 m. Bibit mangga yang dihasilkan untuk ukuran 0,5-0,6 m mencapai 20.000 bibit dalam satu tahun, ukuran $1 \mathrm{~m}$ mencapai 600 bibit dalam satu tahun lebih dan untuk bibit ukuran 2,5 m mencapai 400 bibit dalam dua setengah tahun lebih.

\section{2) Harga (Price)}

Adapun harga bibit Mangga Agrimania yang ditetapkan Agrimania Flora Indramayu berdasarkan harga online pada saat penelitian ini dilakukan dapat dilihat pada Tabel 3.

Tabel 3. Daftar harga bibit Mangga Agrimania usaha pembibitan Mangga Agrimania pada Agrimania Flora Indramayu tahun 2018

\begin{tabular}{|c|c|c|}
\hline $\begin{array}{c}\text { No } \\
\text {. }\end{array}$ & $\begin{array}{c}\text { Ukuran Bibit } \\
\text { Mangga Agrimania }\end{array}$ & $\begin{array}{c}\text { Harga } \\
\text { (Rp/Bibit) }\end{array}$ \\
\hline 1. & Bibit ukuran 0,5-0,6 m & 70.000 \\
\hline 2. & Bibit ukuran $1 \mathrm{~m}$ & 300.000 \\
\hline 3. & Bibit ukuran 2,5 m & 1.500 .000 \\
\hline
\end{tabular}

\section{3) Distribusi (Place)}

Berikut saluran pemasaran Usaha Pembibitan Mangga Agrimania pada Agrimania Flora Indramayu dapat dilihat pada Gambar 3.

\section{Saluran I}

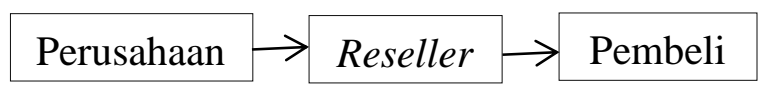

\section{Saluran II}

\section{Perusahaan $\rightarrow$ Pembeli}

Gambar 3. Saluran Pemasaran Usaha Pembibitan Mangga Agrimania pada Agrimania Flora

4) Promosi (Promotion)

Usaha Pembibitan Mangga Agrimania pada Agrimania Flora Indramayu menggunakan media promosi online seperti Facebook, Instagram, situs online agrimaniaflora.com, mengikuti pameran dan menggunakan media cetak seperti brosur. Kemudian setelah perusahaan dikenal oleh masyarakat luas, akan ada beberapa re-seller di beberapa wilayah yang akan memesan produk bibit tersebut dengan batas stok produk yang sudah ditentukan oleh perusahaan setiap tahunnya. 
Deskripsi pekerjaan (Job description) Dalam hal tugas dan tanggung jawab, pemilik usaha sangat mendominasi dalam hal pengontrolan dari seluruh aspek perusahaan baik penyediaan bahan input, proses produksi bibit dan pemasaran.

Tabel 4. Rincian pekerjaan usaha pembibitan Mangga Agrimania pada Agrimania Flora Indramayu

No. Jabatan Jumlah Tugas

1. Pemilik Usaha 1

Pemilik modal, bertanggung jawab terhadap kegiatan pemasaran, pengawasan dan pengarahan kegiatan produksi bibit

Mangga Agrimania.

2. Tenaga Kerja Harian 5

Membuka lahan pembibitan (merangkap sebagai tenaga kerja pada lahan Kelompok Tani Hortikultura Agrimania), memproduksi bibit, dan ikut andil pada pekerjaan fisik memasarkan produk bibit Mangga Agrimania.

\section{Analisis Aspek Finansial}

\section{Proyeksi arus kas}

a. Arus masuk (inflow)

Inflow adalah aliran kas masuk atau pendapatan dari suatu usaha. Sumber pendapatan utama dari perusahaan ini adalah banyaknya penjualan bibit Mangga Agrimania. Jumlah produksi bibit tergantung pada jumlah bahan untuk produksi bibit, banyaknya tenaga kerja dan luas lahan yang tersedia serta jumlah pemesanan yang dilakukan pembeli.

b. Arus keluar (outflow)

Outflow adalah aliran kas yang dikeluarkan oleh suatu usaha. Outflow berupa biaya-biaya yang dikeluarkan baik saat usaha tersebut sedang dibangun maupun saat usaha tersebut sedang berjalan.

\section{1) Biaya investasi}

Berikut merupakan komponen biaya investasi yang tidak dilakukan re-investasi selama umur usaha (umur ekonomis investasi sama dengan umur usaha).

Tabel 5. Investasi usaha selain peralatan

\begin{tabular}{llccr}
\hline No. & \multicolumn{1}{c}{ Investasi } & Satuan & Jumlah Fisik & Jumlah Biaya (Rp) \\
\hline 1. & Tanah & $\mathrm{m}^{2}$ & 500 & 12.000 .000 \\
2. & & 15.400 & 462.000 .000 \\
& Mangga Agrimania & Pohon & 1 & 0 \\
& & BMT & 300 & 540.000 .000 \\
3. & & 300 & 540.000 .000 \\
4. & Alat Transportasi : & Unit & 1 & 171.000 .000 \\
5. & Mobil Pickup & Unit & 1 & 1.000 .000 \\
& Pompa Air (Sanyo) & Unit & 1 & 17.500 .000 \\
6. & (Submersible Pump) & & & 60.000 .000 \\
\hline & Bangunan Kelompok & Unit & 1 & 1.803 .500 .000 \\
\hline
\end{tabular}

Berdasarkan Tabel 5 diatas, diasumsikan Blok Mata Tempel (BMT) Mangga Agrimania dihitung nilai investasinya dengan harga Rp.1.500.000/BMT yang disesuaikan dengan harga jual bibit Mangga Agrimania ukuran 2,5 m. Sedangkan pohon induk tidak dihitung.

Sedangkan untuk peralatan yang digunakan dengan umur ekonomis 10 tahun tidak akan 
memiliki nilai sisa pada akhir periode usaha. Berikut merupakan peralatan yang akan dilakukan reinvestasi.

Tabel 6. Re-investasi selama umur usaha

\begin{tabular}{|c|c|c|c|c|c|}
\hline No. & Peralatan & Satuan & $\begin{array}{l}\text { Jumlah } \\
\text { Fisik }\end{array}$ & $\begin{array}{l}\text { Tahun Re- } \\
\text { Investasi }\end{array}$ & Jumlah Biaya (Rp) \\
\hline 1. & Rumah Bibit & Unit & 1 & 10 & 15.000 .000 \\
\hline 2. & Tangki Air & Unit & 1 & - & 1.000 .000 \\
\hline 3. & $\begin{array}{l}\text { Mesin Pemotong } \\
\text { Rumput }\end{array}$ & Unit & 1 & 9 & 1.675 .000 \\
\hline 4. & Drum Plastik & Unit & 2 & 9 & 480.000 \\
\hline 5. & Arit & Unit & 4 & 6 & 180.000 \\
\hline 6. & Cangkul & Unit & 4 & 6 & 160.000 \\
\hline 7. & Selang Air & $\mathrm{m}^{2}$ & 15.900 & $4,7,10$ & 79.500 .000 \\
\hline 8. & Pisau Grafting & Unit & 4 & $3,5,7,9$ & 240.000 \\
\hline 9. & Gunting Stick & Unit & 4 & $3,5,7,9$ & 120.000 \\
\hline 10. & Keranjang Besar & Unit & 1 & $6,8,10$ & 250.000 \\
\hline 11. & Sapu & Unit & 1 & $\begin{array}{r}2,3,4,5,6 \\
7,8,9,10\end{array}$ & 15.000 \\
\hline 12. & Tempat Sampah & Unit & 1 & $\begin{array}{r}2,3,4,5,6 \\
7,8,9,10\end{array}$ & 10.000 \\
\hline & Total & & & & 98.630 .000 \\
\hline
\end{tabular}

Nilai sisa pada proyeksi arus masuk adalah sebesar Rp.573.548.000. Berikut merupakan komponen investasi yang masih memiiki nilai sisa pada akhir periode umur usaha (Tabel 7).

Tabel 7. Nilai sisa pada akhir periode usaha

\begin{tabular}{ccr}
\hline No. & Investasi & \\
\hline 1. & Lahan & \\
2. & Pompa Air (Sanyo) & 474.000 .000 \\
3. & Pompa Benam (Submersible Pump) & 400.000 \\
4. & Bangunan Kelompok Tani & 8.750 .000 \\
5. & Rumah Bibit & 24.000 .000 \\
6. & Tangki Air & 13.500 .000 \\
7. & Mesin Pemotong Rumput & 300.000 \\
8. & Drum Plastik & 1.005 .000 \\
9. & Selang Air & 288.000 \\
10. & Pisau Grafting & 53.000 .000 \\
11. & Gunting Stick & 120.000 \\
12. & Keranjang Besar & 60.000 \\
& & 125.000 \\
\hline
\end{tabular}

2) Biaya Operasional

Biaya operasional merupakan biaya yang dikeluarkan selama usaha berjalan dimana biaya ini terdiri dari biaya tetap dan biaya variabel. Biaya tetap adalah biaya yang jumlahnya tidak ditentukan oleh banyak output. Sedangkan biaya variabel adalah biaya yang jumlahnya ditentukan oleh banyaknya output, semakin banyak output maka akan semakin banyak biaya yang dikeluarkan. 


\section{Biaya Tetap}

Rincian biaya tetap selama umur usaha dapat dilihat pada Tabel 8.

Tabel 8. Biaya tetap

\begin{tabular}{|c|c|c|c|c|c|}
\hline No. & Struktur Biaya & Satuan & $\begin{array}{l}\text { Jumlah Fisik } \\
\text { Per Tahun }\end{array}$ & $\begin{array}{c}\text { Biaya } \\
\text { Satuan (Rp) }\end{array}$ & $\begin{array}{c}\text { Total Biaya Per } \\
\text { Tahun (Rp) }\end{array}$ \\
\hline 1. & Listrik & Bulan & 12 & 225.000 & 2.700 .000 \\
\hline 2. & PBB & Tahun & 1 & 254.400 & 254.400 \\
\hline 3. & Perlengkapan Kantor & Paket & 12 & 150.000 & 1.800 .000 \\
\hline 4. & Tenaga Kerja Tetap & Bulan & 12 & 4.000 .000 & 48.000 .000 \\
\hline & Total & & & & 4.754 .400 \\
\hline
\end{tabular}

\section{Biaya Variabel}

Tabel 9. Biaya variabel

\begin{tabular}{|c|c|c|c|c|c|c|c|c|c|c|c|}
\hline \multirow[t]{2}{*}{ No. } & \multirow[t]{2}{*}{$\begin{array}{l}\text { omponen Biaya } \\
\text { Variabel }\end{array}$} & \multicolumn{8}{|c|}{ Tahun } & \multirow[b]{2}{*}{9} & \multirow[b]{2}{*}{10} \\
\hline & & 1 & 2 & 3 & 4 & 5 & 6 & 7 & 8 & & \\
\hline 1. & Tanah & $\begin{array}{l}300 . \\
000\end{array}$ & $\begin{array}{r}300 . \\
000\end{array}$ & $\begin{array}{r}1.500 \\
.000\end{array}$ & $\begin{array}{r}3.000 \\
.000\end{array}$ & $\begin{array}{r}6.000 . \\
000\end{array}$ & $\begin{array}{r}6000 . \\
000\end{array}$ & $\begin{array}{l}12.00 \\
0.000\end{array}$ & $\begin{array}{r}12.000 \\
000\end{array}$ & $\begin{array}{r}12.000 \\
000\end{array}$ & $\begin{array}{r}12.000 \\
000\end{array}$ \\
\hline 2. & $\begin{array}{l}\text { Biji Batang Bawah } \\
\text { Pohon Mangga } \\
\text { (Pembibitan) }\end{array}$ & $\begin{array}{r}600 . \\
000\end{array}$ & $\begin{array}{r}600.00 \\
0\end{array}$ & $\begin{array}{r}3.000 \\
.000\end{array}$ & $\begin{array}{r}6.000 \\
.000\end{array}$ & $\begin{array}{r}12.000 . \\
000\end{array}$ & $\begin{array}{l}24.00 \\
0.000\end{array}$ & $\begin{array}{l}24.00 \\
0.000\end{array}$ & $\begin{array}{r}24.000 \\
000\end{array}$ & $\begin{array}{r}24.000 \\
000\end{array}$ & $\begin{array}{r}24.000 . \\
000\end{array}$ \\
\hline 3. & Sekam & $\begin{array}{r}15.00 \\
0\end{array}$ & 15.000 & $\begin{array}{c}65.00 \\
0\end{array}$ & $\begin{array}{l}125 \\
.000\end{array}$ & $\begin{array}{l}250 \\
.000\end{array}$ & $\begin{array}{c}500.0 \\
00\end{array}$ & $\begin{array}{c}500.0 \\
00\end{array}$ & $\begin{array}{r}500 . \\
000\end{array}$ & $\begin{array}{l}500 \\
.000\end{array}$ & $\begin{array}{l}500 . \\
000\end{array}$ \\
\hline 4. & $\begin{array}{l}\text { Pupuk dan } \\
\text { Pestisida }\end{array}$ & $\begin{array}{r}1.000 \\
.000\end{array}$ & $\begin{array}{r}1.000 . \\
000\end{array}$ & $\begin{array}{r}2.500 \\
.000\end{array}$ & $\begin{array}{r}2.500 \\
.000\end{array}$ & $\begin{array}{r}7.500 \\
000\end{array}$ & $\begin{array}{l}15.00 \\
0.000\end{array}$ & $\begin{array}{l}15.00 \\
0.000\end{array}$ & $\begin{array}{r}15.000 \\
000\end{array}$ & $\begin{array}{r}15.000 \\
000\end{array}$ & $\begin{array}{r}15.000 \\
000\end{array}$ \\
\hline 5. & Polybag & $\begin{array}{l}104 . \\
000\end{array}$ & $\begin{array}{l}104 . \\
000\end{array}$ & $\begin{array}{r}442 . \\
000\end{array}$ & $\begin{array}{r}884 . \\
000\end{array}$ & $\begin{array}{l}1.42 \\
.000\end{array}$ & $\begin{array}{r}3.484 \\
.000\end{array}$ & $\begin{array}{r}3.484 \\
.000\end{array}$ & $\begin{array}{r}3.484 . \\
000\end{array}$ & $\begin{array}{r}3.484 . \\
000\end{array}$ & $\begin{array}{r}3.484 . \\
000\end{array}$ \\
\hline 6. & Plastik & $\begin{array}{r}10.00 \\
0\end{array}$ & 10.000 & $\begin{array}{l}10.00 \\
0\end{array}$ & $\begin{array}{r}10.00 \\
0\end{array}$ & 20.000 & 40.000 & $\begin{array}{l}40.00 \\
0\end{array}$ & 40.000 & 40.000 & 40.000 \\
\hline 7. & Tenaga Kerja & - & - & $\begin{array}{l}57.60 \\
0.000\end{array}$ & $\begin{array}{r}129.6 \\
00.00 \\
0\end{array}$ & $\begin{array}{r}180.00 \\
0.000\end{array}$ & $\begin{array}{r}216.0 \\
00.00 \\
0\end{array}$ & $\begin{array}{r}216.0 \\
00.00 \\
0\end{array}$ & $\begin{array}{r}216.00 \\
0.000\end{array}$ & $\begin{array}{r}216.00 \\
0.000\end{array}$ & $\begin{array}{r}216.00 \\
0.000\end{array}$ \\
\hline & Total & $\begin{array}{r}2.029 \\
.000\end{array}$ & $\begin{array}{r}2.029 . \\
000\end{array}$ & $\begin{array}{l}65.11 \\
7.000\end{array}$ & $\begin{array}{r}142.1 \\
19.00 \\
0 \\
\end{array}$ & $\begin{array}{r}207.51 \\
2.000\end{array}$ & $\begin{array}{r}271.0 \\
24.00 \\
0 \\
\end{array}$ & $\begin{array}{r}271.0 \\
24.00 \\
0 \\
\end{array}$ & $\begin{array}{r}271.02 \\
4.000\end{array}$ & $\begin{array}{r}271.02 \\
4.000\end{array}$ & $\begin{array}{r}271.02 \\
4.000\end{array}$ \\
\hline
\end{tabular}

\section{Analisis Laba Rugi}

Tabel. 10. Rekapitulasi proyeksi laba rugi

\begin{tabular}{lr}
\hline \multicolumn{1}{c}{ Uraian } & Nilai $(\mathrm{Rp})$ \\
\hline Total laba & 14.079 .631 .000 \\
Rata-rata laba per tahun & 1.407 .963 .100 \\
Total pajak & 4.465 .000 \\
Rata-rata pajak & 446.500 \\
\hline
\end{tabular}

Hasil perhitungan laba rugi memperlihatkan bahwa total akumulasi pajak selama 10 tahun yakni sebesar Rp.4.465.000 sedangkan akumulasi laba bersih setelah pajak yang diperoleh sebesar Rp.14.079.631.000 atau 81\% dari total akumulasi penerimaan selama umur usaha. 


\section{Analisis Kelayakan Investasi}

Mangga Agrimania pada Agrimania Flora Indramayu digunakan kriteria investasi seperti R/C, NPV, IRR, Net B/C dan Payback Periode. Berikut hasil analisis kriteria investasi (Tabel 11.)

Tabel 11. Rekapitulasi hasil perhitungan kriteria investasi

\begin{tabular}{lr}
\hline \multicolumn{1}{c}{ Uraian } & Nilai \\
\hline R/C & 5,41 \\
PV negatif (Rp) & $574.294 .684,00$ \\
PV positif (Rp) & $3.758 .351 .046,00$ \\
NPV (Rp) & $3.184 .056 .362,63$ \\
IRR & $67 \%$ \\
Net B/C & 6,54 \\
Rata-rata PV per tahun (Rp) & 318.405 .636 \\
PP & 4,07 \\
PP (tahun. bulan. hari) & 4 tahun 2 bulan 10 hari \\
\hline Total PV inflow (Rp) & $5.557 .228 .946,00$ \\
\hline
\end{tabular}

1. Revenue Cost Ratio (R/C)

Pada perhitungan $\mathrm{R} / \mathrm{C}$ adalah pembagian dari penerimaan total dengan biaya total selama umur usaha (10 tahun) diperoleh nilai $\mathrm{R} / \mathrm{C}$ sebesar 5,41. Nilai $\mathrm{R} / \mathrm{C}$ pada usaha pembibitan Mangga Agrimaniapada Agrimania Flora Indramayu ini adalah R/C $>1$ yang artinya layak untuk dijalankan karena usaha ini memberikan pengembalian yang tinggidari investasi $(\mathrm{R} / \mathrm{C}>1)$.

\section{2. $\quad$ Net Present Value (NPV)}

Berdasarkan nilai PV positif dan PV negatif tersebut akan didapatkan nilai NPV sebesar Rp.3.184.056.362,63 yang berarti bahwa usaha pembibitan Mangga Agrimania pada Agrimania Flora Indramayu akan menghasilkan manfaat bersih sebesar Rp.3.184.056.362,63 atau 57\% dari akumulasi nilai kini inflow yang diperoleh selama umur usaha (10 tahun). Dari uraian tersebut dapat diketahui bahwa usaha pembibitan Mangga Agrimania pada Agrimania Flora Indramayu layak untuk dilaksanakan karena NPV yang diperoleh dari hasil perhitungan kriteria investasi lebih besar dari nol $(\mathrm{NPV}>0)$.

\section{Internal Rate of Return (IRR)}

Nilai IRR sebesar $67 \%$ berarti bahwa tingkat pengembalian usaha pembibitan Mangga Agrimania pada Agrimania Flora Indramayu terhadap investasi yang ditanamkan sebesar $67 \%$. Artinya memiliki nilai yang lebih besar dibandingkan dengan nilai cost of capital yang telah ditentukan yaitu sebesar 17,5\% (IRR>DR) sehingga usaha pembibitan Mangga Agrimania pada Agrimania Flora Indramayu layak untuk dilaksanakan.

\section{Net Benefit Cost Ratio (Net B/C)}

Pada perhitungan Net B/C dalam analisis kriteria investasi diperoleh nilai Net B/C sebesar 6,54. Hal ini berarti setiap tambahan biaya sebesar Rp.1.00 dapat menghasilkan tambahan manfaat bersih sebesar Rp.6,54. Nilai Net B/C pada usaha pembibitan Mangga Agrimania pada Agrimania Flora Indramayu ini lebih besar dari satu sehingga usaha ini layak untuk dilaksanakan (Net B/C $>1$ ).

\section{Payback Period (PP)}

Informasi ini menyatakan bahwa seluruh biaya investasi dapat dikembalikan dalam jangka waktu 4 tahun 2 bulan 10 hari. Bila dibandingkan dengan umur usaha yakni selama 10 tahun, maka jangka waktu pengembalian modal usaha lebih cepat daripada umur usaha sehingga usaha pembibitan Mangga Agrimania pada Agrimania Flora Indramay layak untuk dilaksanakan. 


\section{Analisis Nilai Pengganti}

Analisis nilai pengganti (switching value) digunakan untuk mengetahui seberapa besar perubahan maksimal pada biaya input produksi yang dapat ditolerir sehingga usaha yang dilakukan masih layak dilaksanakan. Nilai pengganti (switching value) ditentukan dengan uji coba sehingga menghasilkan NPV yang sama dengan nol atau mendekati nol, IRR mendekati discount rate dan nilai Net B/C sama dengan satu.

Tabel 12. Hasil analisis nilai pengganti terhadap kenaikan harga input produksi

\begin{tabular}{lccr}
\hline Kriteria Investasi & Kondisi Normal & $\begin{array}{c}\text { Kenaikan Harga Biji Batang } \\
\text { Bawah Tanaman } \\
\text { Mangga (Pembibitan) }\end{array}$ & $\begin{array}{c}\text { Kenaikan Harga Pupuk } \\
\text { dan Pestisida 11.080\% }\end{array}$ \\
\hline PV Negatif & $7.140 \%$ & 916.481 .752 \\
PV Positif & 574.294 .684 & 771.029 .265 & 920.749 .920 \\
R/C & 3.758 .351 .046 & 773.387 .973 & 1,33 \\
NPV & 5,41 & 1,31 & $4.268 .168,23$ \\
IRR & $3.184 .056 .362,63$ & $2.358 .708,25$ & $17,58 \%$ \\
Net B/C & $67 \%$ & $17,55 \%$ & 1,00 \\
Rata-rata PV per tahun & $318.405 .636,263$ & $235.870,82$ & $426.816,823$ \\
Payback Period & 4,07 & 5,93 & 5,81 \\
Discounted Payback Period & 5,07 & 9,99 & 9,99 \\
PV Inflow & 5.557 .228 .946 & 5.557 .228 .946 & $0 \%$ \\
\% NPV terhadap PV Inflow & $57 \%$ & $0 \%$ & 5.557 .228 .946 \\
\hline
\end{tabular}

\section{SIMPULAN DAN SARAN}

\section{Simpulan}

Hasil penelitian yang telah dilakukan pada Usaha Pembibitan Mangga Agrimania pada Agrimania Flora Indramayu di Desa Jatisura Kecamatan Cikedung Kabupaten Indramayu dapat diambil beberapa kesimpulan sebagai berikut :

1. Berdasarkan analisis dari aspek non finansial, Usaha Pembibitan Mangga Agrimania pada Agrimania Flora Indramayu telah layak secara keseluruhan, namun perlu adanya perbaikan pada aspek manajemen dan hukum.

2. Hasil analisis aspek finansial pada Usaha Pembibitan Mangga Agrimania dengan adanya penambahan lahan ini layak untuk dijalankan. Dilihat dari nilai $\mathrm{R} / \mathrm{C}$ adalah lebih dari 1 yaitu sebesar 5,41, NPV lebih dari nol yaitu sebesar Rp.3.184.056.362,63, IRR lebih dari tingkat discount rate yaitu sebesar 67\%, Net B/C lebih besar dari satu yaitu 6,54 dan Payback Periode kurang dari umur usaha yaitu selama 4 tahun 2 bulan 10 hari. Arti data tersebut menunjukkan bahwa perusahaan secarafinansial layakuntukdijalankan.

3. Hasil analisis nilai pengganti (switching value) menunjukkan bahwa usaha pembibitan Mangga Agrimania pada Agrimania Flora Indramayu tidak sensitif terhadap kenaikan harga input. Jika kenaikan harga beli bahan biji batang bawah tanaman mangga meningkat lebih dari $7.140 \%$ atau kenaikan harga pupuk dan pestisida meningkat lebih dari $11.080 \%$ maka usaha pembibitan Mangga Agrimania pada Agrimania Flora Indramayu menjadi tidak layak untuk dilaksanakan.

\section{Saran}

Saran untuk penelitian selanjutnya yaitu variabel yang diteliti adalah analisis kelayakan usaha pembibitan Agrimania Flora Indramayu secara keseluruhan, tidak hanya pembibitan pada komoditas mangga tetapi pembibitan pada tanaman buah yang lain, seperti durian, jambu, kelengkeng dan lainnya. 


\section{Ucapan Terimakasih}

Ucapan Terimaksih saya ucapkan kepada pihak terkait dalam penelitian ini baik eksternal maupun internal yang telah membantu penelitian .

\section{DAFTAR PUSTAKA}

Anajohn, J. 2014 Analisis Kelayakan Usaha Jaboticaba (Myrciaria cauliflora) Di Kecamatan Lembang Jawa Barat. Fakultas Ekonomi dan Manajemen. Institut Pertanian Bogor. Bogor.

Badan Penelitian dan Pengembangan Pertanian. 2015. Inovasi Hortikultura Pengungkit Peningkatan Pendapatan Rakyat. Jakarta: Badan Penelitian dan Pengembangan Pertanian.

Badan Pusat Statistik Kabupaten Indramayu. 2015. Profil Desa Jatisura. Indramayu: Badan Pusat Statistik.

Badan Pusat Statistik Kabupaten Indramayu. 2018. Kabupaten Indramayu Dalam Angka 2018. Indramayu: Badan Pusat Statistik.

Badan Pusat Statistik. 2018. Statistik Indonesia. Jakarta: Badan Pusat Statistik.

Balai Penelitian Tanah. 2008. Budidaya Tanaman Mangga (Mangifera indica L.). Bogor: Badan Penelitian dan Pengembangan Pertanian

Balai Penelitian Tanaman Buah Tropika. 2014. Mangga Gedong Gincu dan Kesehatan. Sumatera Barat: Badan Penelitian dan Pengembangan Pertanian.

Dinas Pertanian Kabupaten Indramayu. 2018. Uji Keunggulan Mangga Varietas Agrimania. Dinas Pertanian Kabupaten Indramayu. Indramayu

Dinas PU PR Stasiun Kecamatan Cikedung Kabupaten Indramayu. 2018. Data Curah Hujan Sepuluh Tahun Terakhir di Kecamatan Cikedung. Dinas PU PR Stasiun Kecamatan Cikedung Kabupaten Indramayu. Indramayu

Gittinger, J. P. 1986. Analisa Ekonomi Proyek-Proyek Pertanian. Ed ke-2. Slamet S. Komet M. Penerjemah; Jakarta: UI Press. Terjemahan dari: Economic Analysis of Agriculture Project.

Halim, H. A. 2016. Produksi Mangga Indramayu Turun 40\%.www.pikiran-rakyat.com. Diakses tanggal 28 Oktober 2018

Husnan S, dan Muhammad S. 2005. Studi Kelayakan Proyek. Yogyakarta: UPP AMP YKPN.

IPGRI. 2006. Descriptors for Mango (Mangifera indica L.). International Plant Genetic Resources Institute. Rome, Italy.

Juniatno, E. T. 2014. Analisis Kelayakan Usaha Bandeng (Chanos-chanos) Tanpa Duri Pada CV. Elfath Di Desa Karangsong Kabupaten Indramayu. Fakultas Pertanian, Universitas Wiralodra. Indramayu.

Kadariah. 1999. Pengantar Evaluasi Proyek. Jakarta : Fakultas Ekonomi Universitas Indonesia.

Kusrina, R. 2011. Analisis Kelayakan Usaha Pengolahan Kerupuk Perusahaan Kerupuk Cap Dua Gajah Indramayu, Jawa Barat. Departemen Agribisnis. Fakultas Ekonomi dan Manajemen. Institut Pertanian Bogor. Bogor. 
Nazir, M. 2011. Metode Penelitian. Cetakan Ketujuh. Penerbit Ghalia Indonesia. Bogor

Rustiana N. I. 2008. Analisis Kelayakan Usaha Puree Mangga (Mangifera Indica L.) Studi Kasus Pada CV. Promindo Utama, Desa Losari Lor, Kecamatan Losari, Kabupaten Cirebon, Jawa Barat. Fakultas Pertanian. Institut Pertanian Bogor. Bogor

Nurmalina R, Sarianti T, Karyadi A. 2009. Studi Kelayakan Bisnis. Bogor: Departemen Agribisnis. Fakultas Ekonomi dan Manajemen. Institut Pertanian Bogor.

Oktavianto, Sunaryo, Suryanto. 2015. Karakterisasi Tanaman Mangga (Mangifera indica L.) Cantek, Ireng, Empok, Jempol Di Desa Tiron, Kecamatan Banyakan Kabupaten Kediri. Fakultas Pertanian. Universitas Brawijaya. Malang. Jurnal Produksi Tanaman Volume 3 Nomor 2, Maret 2015, hlm. 91-97.

Pracaya. 2001. Bertanam Mangga. Cetakan XVII. Edisi Revisi. Jakarta: Penebar Swadaya.

Prastowo, Roshetko, Maurung, Nugraha, Tukan, Harum. 2006. Teknik Pembibitan dan Perbanyakan Vegetatif Tanaman Buah. World Agroforestry Centre (ICRAF) dan Winrock International. Bogor, Indonesia

Salamtani.id. Mangga Agrimania Unggul dan Termahal Di Indonesia. Www.Salamtani.Id . Diakses tanggal 15 Oktober 2018

Situmorang, S. H. 2007. Studi Kelayakan Bisnis. Cetakan Kesatu. Medan: USU Press

Soekartawi. 1995. Analisis Usahatani. Penerbit Universitas Indonesia (UI- Press). Jakarta

Soekartawi. 1999. Agribisnis Teori dan Aplikasi. Jakarta. PT. Raja Grafindo Persada.

Soeharto, I. 1999. Manajemen Proyek (Dari Konseptual Sampai Operasional). Edisi Kedua. Jilid 1. Konsep, Studi Kelayakan, dan

Jaringan Kerja. Jakarta: Penerbit Erlangga.

Sudiyono A. 2002. Pemasaran Pertanian.Malang: UMM Press.

Sulastri, L. 2016. Studi Kelayakan Bisnis Untuk Wirausaha. Cetakan Pertama. LaGood's Publishing

Umar, H. 2005. Studi Kelayakan Bisnis. Jakarta: Gramedia Pustaka Utama.

Walidin W, Saefullah, Tabrani. 2015. Metodologi Penelitian Kualitatif \& Grounded Theory. Cetakan Kesatu. FTK Ar-Raniry Press (Fakultas Tarbiyah dan Keguruan UIN Ar- Raniry). Aceh. 